\title{
Canada's Patented Medicines (Notice of Compliance) Proceedings and Intellectual Property
}

\author{
Henry Bian and Conor McCourt ${ }^{1}$ \\ Intellectual Property Group, Torys LLP, Toronto, Ontario M5K 1N2, Canada \\ Correspondence: hbian@torys.com
}

Canada's Patent Register is a tool created by the Patented Medicines (Notice of Compliance) Regulations to help innovators protect their inventions relating to pharmaceuticals. This tool exists at the intersection between the intellectual property and drug approval regimes. By listing a patent on the Patent Register, an innovator can prevent a generic manufacturer from entering the marketplace rather than having to wait for his or her patent to be infringed. This article provides information on the requirements for listing a patent on the Patent Register and an overview of how the Patent Medicines (Notice of Compliance) Regulations affect the drug approval process.

Eureka! After countless hours in a laboratory Eand more cups of coffee than you can count, you have discovered the next blockbuster drug. Your discovery will help numerous people, but can you also use it to gain some reward for your hard work?

One tool that can help you realize a return is to obtain a patent for your invention. In exchange for disclosing to the public what your invention is and how to practice it, you are granted a monopoly for your invention for a certain period of time. This prevents anyone else from manufacturing, selling, using, or importing your invention. Further, if they infringe any of your patent rights, you can pursue legal action in the courts.

However, patent rights are typically enforceable only after someone has entered the market and already infringed your patent rights. Even then the infringement will likely continue for a period of time, because only very rarely will a court in Canada restrain a competitor from infringing when a case has not yet been decided. Typically, a competitor is required to stop infringing only after a lengthy and expensive lawsuit that can last years. Is there an immediate way to prevent someone else infringing your patent rights?

\section{CANADA'S PATENT REGISTER}

In Canada an innovator can use the Patented Medicines (Notice of Compliance) Regulations (PM(NOC) Regulations) to prevent competitors from entering the marketplace, even before there is an infringement of patent rights. These

\footnotetext{
${ }^{1}$ Partner and co-chair.

Editors: Salim Mamajiwalla and Rochelle Seide

Additional Perspectives on Intellectual Property in Molecular Medicine available at www.perspectivesinmedicine.org

Copyright (C) 2015 Cold Spring Harbor Laboratory Press; all rights reserved; doi: 10.1101/cshperspect.a020842

Cite this article as Cold Spring Harb Perspect Med 2015;5:a020842
} 
regulations exist at the intersection between patent rights and the drug regulatory approval system. The PM(NOC) Regulations operate to prevent regulatory approval from being granted to a competitor until the competitor establishes that its allegations of invalidity or noninfringement of the innovator's patent rights are justified.

To sell a drug in Canada, both innovative and generic manufacturers must first obtain regulatory approval from Health Canada by submitting a drug submission. This submission must include information for Health Canada to evaluate the safety and efficacy of the drug. If the submission is successful, the manufacturer receives marketing authorization from Health Canada, called a notice of compliance, or NOC.

The PM(NOC) Regulations create a Patent Register with Health Canada on which an innovator may list patents that are relevant to its various drug submissions for regulatory approval. The patent list becomes a minefield that a generic "copycat" manufacturer must navigate around to obtain an approval on generic versions of the drug.

\section{Listing on the Patent Register}

To list a patent on the Patent Register, there are a number of requirements relating to timing of the patent list submission and subject matter eligibility for both the drug submission and the patent.

\section{Patent Lists-Timing Requirements}

To file a patent list for a particular drug, you will need to meet certain timing requirements. These requirements differ depending on when your patent issues. The list must contain only issued patents and may not contain patent applications.

For patents that were already issued before a drug submission is filed with Health Canada, a patent list must be filed with the drug submission. If this is not done, the patents will not be listed on the Patent Register and you will not be able to take advantage of the benefits of the PM(NOC) Regulations.

For patents issued after a drug submission is filed, you will still be able to file a patent list if two conditions are met: (1) the Canadian filing date of the patent precedes the drug submission filing date; and (2) the patent list is submitted within 30 days of the grant of the patent. These are strict time limits and cannot be extended.

\section{Patent Lists - Eligible Drug Submissions}

Your drug submission must also be of an eligible type against which to file a patent list. For a drug submission to be eligible, it must be one of the following types of submissions:

- a New Drug Submission, except a New Drug Submission based solely on the change of name of the manufacturer or of the drug;

- a supplement to a New Drug Submission for a change in formulation;

- a supplement to a New Drug Submission for a change in the dosage form;

- a supplement to a New Drug Submission for a change in use of the medicinal ingredient.

\section{Patent Lists-Eligible Patent Claims and Relevance Requirements}

Your patent must also be eligible for listing on the Patent Register. There are requirements for claim type and relevance to your drug submission.

The first requirement for eligibility to list your patent is that your patent must contain certain types of claims:

- a claim for the medicinal ingredient;

- a claim for the formulation that contains the medicinal ingredient;

- a claim for the dosage form;

- a claim for the use of the medicinal ingredient.

Other types of patent claims are not eligible for listing on the Patent Register. These include claims to a process for making a drug, claims to a medical device, and claims to a metabolite of the drug.

As you can see, the types of drug submissions and types of patent claims are similar in nature. 
This leads to the key requirement for listing a patent: There must be a subject matter correspondence between the patents in the patent list and the drug submission for a patent list to be eligible for inclusion on the Patent Register.

Further, your patent must be active. Patents that have lapsed or expired cannot be listed on the Patent Register. The term of your patent lasts for up to 20 years from the Canadian filing date of the patent. You must pay annual maintenance fees to keep your patent active.

\section{Entry of a Generic Product}

As mentioned above, a generic manufacturer that wishes to file a generic version of a drug must also file a drug submission. However, generic manufacturers will often submit less information relating to the safety of the drug and rely on the safety information provided by an innovator for the same drug by showing that they are bioequivalent. If the generic drug is bioequivalent, Health Canada assumes that the research and clinical work that shows the innovator's drug to be safe and effective would equally apply to the generic drug.

If the generic manufacturer does not want to wait for the patents to expire to make a generic version of a drug, it can allege that the patents listed against the drug are not valid or that the patents are not applicable to its proposed product (i.e., that it does not infringe).

The allegation is typically met with an application by the patent owner under the PM(NOC) Regulations asking the Federal Court to prohibit Health Canada from approving the generic drug. By filing this application, Health Canada's decision on whether to grant the approval for the generic drug is frozen for 24 months or until the disposition of the application in Federal Court, whichever is earlier. This period acts like an absolute injunction, preventing generic manufacturers from entering the market.

The Federal Court will decide whether the generic manufacturer has established its allega- tion that the patents are not infringed and/or are invalid. If the generic manufacturer wins, then an NOC for the generic drug will be issued by Health Canada. If the generic manufacturer loses, then it will not receive an NOC for the generic drug until expiry of all of the patents on the Patent Register. The generic manufacturer can appeal a loss to the Federal Court of Appeal.

A losing innovator does not have the option to file an appeal because the NOC is issued immediately, and the Federal Court of Appeal has taken the position that any such appeal is therefore moot. The innovator can, however, still initiate "regular" patent infringement proceedings if it believes that the generic manufacturer is infringing its patent rights despite the result in the proceeding under the $\mathrm{PM}(\mathrm{NOC})$ Regulations.

\section{Comprehensive Economic and Trade Agreement}

On September 26, 2014, a Comprehensive Economic and Trade Agreement (CETA) between Canada and Europe was published, following an agreement in principle reached between the parties on October 18, 2013. As part of this agreement, Canada will need to amend its patent laws and regulations. These changes will affect the process under the PM(NOC) Regulations.

As mentioned above, at present, if an innovator loses at the Federal Court, Health Canada will issue an NOC and allow a generic manufacturer to start marketing the drug. The innovator does not have the option to appeal this decision. However, if a generic company loses at the trial level, it can appeal the decision. Under CETA, it is provided that the contracting States agree to provide all litigants with "equivalent and effective rights of appeal." It is unclear at this time how that right of appeal in favor of an innovator will actually be implemented under the definitive agreement with Europe, as it depends on the precise implementation in domestic law by the Canadian Government. 


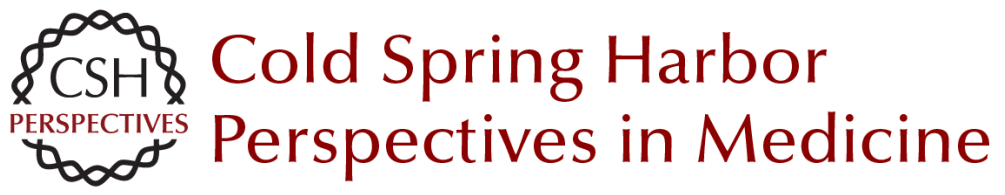

\section{Canada's Patented Medicines (Notice of Compliance) Proceedings and Intellectual Property}

Henry Bian and Conor McCourt

Cold Spring Harb Perspect Med 2015; doi: 10.1101/cshperspect.a020842 originally published online January 8, 2015

Subject Collection Intellectual Property in Molecular Medicine

Patentability of Stem Cells in the United States Sarah E. Fendrick and Donald L. Zuhn, Jr.

Inventorship and Authorship

Antoinette F. Konski and Linda X. Wu

The Patentability of Stem Cells in Australia Jenny Petering and Prue Cowin

Impact of America Invents Act on Biotech

Intellectual Property

Amanda Murphy, Michael Stramiello, Jonathan

Stroud, et al.

Introduction to Intellectual Property: A U.S.

Perspective

Amanda Murphy, Michael Stramiello, Stacy Lewis, et al.

The Role of Regulatory Agencies and Intellectual

Property: Part I

Kevin E. Noonan

Canada's Patented Medicines (Notice of

Compliance) Proceedings and Intellectual

Property

Henry Bian and Conor McCourt

Patentability of Genes: A European Union

Perspective

Paul Cole
The Impact of Myriad on the Future Development and Commercialization of DNA-Based Therapies and Diagnostics

Michele Wales and Eddie Cartier

Protecting Traditional Knowledge Related to

Biological Resources: Is Scientific Research

Going to Become More Bureaucratized?

Prashant Reddy and Malathi Lakshmikumaran

Protecting Trade Secrets in Canada Noel Courage and Janice Calzavara

Inherent Anticipation in the Pharmaceutical and

Biotechnology Industries

Michael Goldman, Georgia Evans and Andrew Zappia

The Role of Regulatory Agencies and Intellectual

Property: Part II Kevin E. Noonan

Baseball Bats and Chocolate Chip Cookies: The Judicial Treatment of DNA in the Myriad Genetics Litigation Ian Binnie and Vanessa Park-Thompson

The Impact of Myriad and Mayo: Will

Advancements in the Biological Sciences Be

Spurred or Disincentivized? (Or Was Biotech

Patenting Not Complicated Enough?) Jennifer Gordon

Trade Secrets in Life Science and Pharmaceutical Companies

Tara Nealey, Ronald M. Daignault and Yu Cai

For additional articles in this collection, see http://perspectivesinmedicine.cshlp.org/cgi/collection/ 